\title{
Sustainable Mortars with Incorporation of Microencapsulated Phase Change Materials
}

\author{
CUNHA Sandra ${ }^{1, a}$, AGUIAR José ${ }^{1, b}$, ZALEGOWSKI Kamil ${ }^{2, c}$, \\ GARBACZ Andrzej ${ }^{2, \mathrm{~d}}$, SOARES Patrícia ${ }^{1, \mathrm{e}}$, AZEVEDO Juliana ${ }^{1, \mathrm{f}}$, \\ FERREIRA Victor ${ }^{3,9}$ and TADEU António ${ }^{4, h}$ \\ ${ }^{1}$ University of Minho, Campus de Azurém, 4800-058 Guimarães, Portugal \\ ${ }^{2}$ Warsaw University of Technology, DMBE, Armii Ludowej 16, PL 00637 Warsaw, Poland \\ ${ }^{3}$ University of Aveiro, Campus Universitário de Santiago, 3810-193 Aveiro, Portugal \\ ${ }^{4}$ University of Coimbra, Rua Luís Reis Santos - Pólo II da Universidade, 3030-788 Coimbra, \\ Portugal \\ asandracunha86@gmail.com, baguiar@civil.uminho.pt, 'ck.zalegowski@il.pw.edu.pl, \\ da.garbacz@il.pw.edu.pl, patriciarvs3@gmail.com, fjulianazevedo@live.com.pt, ${ }^{\mathrm{g} v i c t o r f @ u a . p t, ~}$ \\ tadeu@dec.uc.pt
}

Keywords: Mortar; Phase change material; Fly ash; Physical properties; Mechanical properties.

Abstract. . The construction industry is responsible for high energy and raw materials consumption. Thus, it is important to minimize the high energy consumption by taking advantage of renewable energy sources and reusing industrial waste, decreasing the extraction of natural materials. The mortars with incorporation of phase change materials (PCM) have the ability to regulate the temperature inside buildings, contributing to the thermal comfort and reduction of the use of heating and cooling equipment, using only the energy supplied by the sun. The simultaneous incorporation of PCM and fly ash (FA) can reduce the energy consumption and the amount of materials landfilled. However, the addition of these materials in mortars modifies its characteristics. The main purpose of this study was the production and characterization in the fresh and hardened state of mortars with incorporation of different contents of PCM and FA. The binders studied were aerial lime, hydraulic lime, gypsum and cement. The proportion of PCM studied was $0 \%, 20 \%, 40 \%$ and $60 \%$ of the mass of the sand. The content of fly ash added to the mortars was $0 \%, 20 \%, 40 \%$ and $60 \%$ of the mass of the binder. It was possible to observe that the incorporation of PCM and fly ash in mortars caused differences in properties such as workability, microstructure, water absorption, compressive strength, flexural strength and adhesion.

\section{Introduction}

Every year the energy powered by the sun that reaches the entire land surface is about 10000 times higher than the actual energy consumption per year worldwide. Thus, the need to find a way to take advantage of this natural energy source is pressing [1].

It is known that the largest part of the energy consumption in construction industry, specifically in residential sector is associated with the needs for heating and cooling. This problem is related with the excessive use of energy from nonrenewable sources, which causes serious environmental impacts. On other hand, in recent years, the production of wastes increased in the entire world. Therefore, it becomes imperative to obtain new constructive solutions that minimize the energy consumptions and reuse wastes, improving the quality of construction and contributing to the quality of the environment.

The incorporation of Phase Change Materials (PCM) in mortars for the interior appears as a possible solution in an attempt to solve, or at least minimize, the massive energy consumption related with buildings. The use of this material allows the regulation of temperature inside buildings through latent heat thermal energy storage, using only solar energy as a resource. Thus, the 
development of new construction materials with incorporation of this material, with the aim to improve the comfort level of the buildings, especially with regard to thermal comfort is urgent.

Some studies have been published incorporating PCM in construction products. The incorporation of phase change materials in gypsum plasterboard has been the subject of several studies performed, due to its low cost and various possibilities of application [2-5]. Darkwa et al. [4], investigated the behavior of two solutions with incorporation of PCM in gypsum plasterboard. In one side the plasterboard used had $12 \mathrm{~mm}$ of thickness, all impregnated with PCM in order to compare with another situation in which they applied single plasterboards with $10 \mathrm{~mm}$ of thickness, covered by PCM laminate with $2 \mathrm{~mm}$. The amount of PCM incorporated in both cases was the same. The results showed that the use of PCM laminate is more efficient since it contributed to an increase in the minimum temperature. However, other solutions had also been developed like alveolar PVC panels with PCM macroencapsulated, blocks and bricks [6-7]. Cabeza et al. [6] constructed and monitored the behavior of concrete test cells, with and without addition of 5\% of PCM microcapsules. The incorporation of PCM was made in the concrete used on the roof and south and west walls. During the summer and without ventilation a decrease in maximum temperature and a time lag of about 2 hours were recorded.

The main objective of this work was the study of mortars with PCM incorporation based in different binders and cement based mortars with incorporation of fly ash. Tests were performed with 11 different compositions, evaluating some properties in the fresh and hardened state, such as workability, microstructure, water absorption, flexural strength, compressive strength and adhesion.

\section{Experimental program}

Materials. The selection of the materials took into account previous works [8-10]. Mortars for interior coating based on the following binders: aerial lime, hydraulic lime, gypsum and cement were developed. The aerial lime used has a purity of $90 \%$ and density of $2450 \mathrm{~kg} / \mathrm{m}^{3}$, with calcium oxide $(\mathrm{CaO})$ as only chemical component. The gypsum used is a traditional one, with high fineness and density of $2740 \mathrm{~kg} / \mathrm{m}^{3}$. The hydraulic lime was a natural lime (NHL5) with density of 2550 $\mathrm{kg} / \mathrm{m}^{3}$. The chemical components of hydraulic lime are calcium oxide $(\mathrm{CaO})$, potassium oxide $\left(\mathrm{K}_{2} \mathrm{O}\right)$, aluminum oxide $\left(\mathrm{Al}_{2} \mathrm{O}_{3}\right)$, silicium oxide $(\mathrm{SiO} 2)$ and magnesium oxide $(\mathrm{MgO})$. A cement CEM II B-L $32.5 \mathrm{~N}$ with density of $3030 \mathrm{~kg} / \mathrm{m}^{3}$ was also used.

The PCM used is composed by a wall made by using melamine-formaldehyde and a core in paraffin, with temperature transition of about $22.5^{\circ} \mathrm{C}$ and enthalpy of $147.9 \mathrm{~kJ} / \mathrm{kg}$. This exhibits a transition temperature of $24^{\circ} \mathrm{C}$ in the heating cycle and $21{ }^{\circ} \mathrm{C}$ in the cooling cycle. The process of fabrication is polycondensation by addition and the material is commercialized by the Devan Chemicals, with the commercial name of Mikathermic D24. The dimensions of PCM microcapsules were evaluated by granulometry tests, using a laser particle size analyzer. It was possible to observe a particle size distribution between 5.8 to $339 \mu \mathrm{m}$, with $80 \%$ of particle size between 10.4 to 55.2 $\mu \mathrm{m}$. The average particle size is $43.91 \mu \mathrm{m}$.

The superplasticizer used was a polyacrylate, with a density of $1050 \mathrm{~kg} / \mathrm{m}^{3}$.

The sand used has an average particle size of $439.9 \mu \mathrm{m}$ and a density of $2600 \mathrm{~kg} / \mathrm{m}^{3}$. Based in granulometric distribution the parameters D50, D10 and D90 were obtained. The D10 correspond to $150 \mu \mathrm{m}, \mathrm{D} 50$ correspond to $310 \mu \mathrm{m}$ and the D90 correspond to $480 \mu \mathrm{m}$.

The fly ash used was derived from the combustion of coal in thermoelectric central of Pego in Portugal, with density of $2420 \mathrm{~kg} / \mathrm{m}^{3}$.

Finally, synthetic fibers of polyamide, with a length of $6 \mathrm{~mm}$, a $22.3 \mu \mathrm{m}$ of thickness and a density of $1380 \mathrm{~kg} / \mathrm{m}^{3}$ were used.

Formulations. In order to develop this study an experimental methodology was considered, with the main goal of characterizing the produced compositions. Eleven compositions were developed taking account the future application of the mortar for interior coating. These compositions were evaluated from the fresh state up to 28 days.

The PCM content was fixed in $0 \%, 20 \%, 40 \%$ and $60 \%$ of total mass of aggregate. The fly ash content was $0 \%, 20 \%, 40 \%$ and $60 \%$ of mass of cement. In order to overcome some of the problems 
related with the mortar shrinkage and consequent cracking, polyamide fibers and superplasticizer were incorporated. The content of PCM, fibers and superplasticizer was based in previous works [810]. The studied compositions are presented in Table 1.

Table 1. Mortars formulation $\left(\mathrm{kg} / \mathrm{m}^{3}\right)$.

\begin{tabular}{|c|c|c|c|c|c|c|c|c|}
\hline Composition & \multicolumn{2}{|c|}{ Binder } & Sand & PCM & Superplasticizer & Fibers & Fly ash & Water \\
\hline AL500-0PCM & Aerial Lime & 500 & 1447.2 & 0 & 15 & 0 & 0 & 225 \\
\hline AL800-40PCM-F & Aerial Lime & 800 & 425.2 & 170.1 & 24 & 8 & 0 & 288 \\
\hline HL500-0PCM & Hydraulic lime & 500 & 1351.1 & 0 & 15 & 0 & 0 & 270 \\
\hline HL500-40PCM-F & Hydraulic lime & 500 & 567.2 & 226.9 & 15 & 5 & 0 & 310 \\
\hline G500-0PCM & Gypsum & 500 & 1360.4 & 0 & 15 & 0 & 0 & 280 \\
\hline G500-40PCM-F & Gypsum & 500 & 535.8 & 214.3 & 15 & 5 & 0 & 350 \\
\hline C500-0PCM & Cement & 500 & 1418.8 & 0 & 15 & 0 & 0 & 275 \\
\hline C500-40PCM-F & Cement & 500 & 622.2 & 248.8 & 15 & 5 & 0 & 295 \\
\hline $\begin{array}{c}\text { C400FA100- } \\
\text { 40PCM-F }\end{array}$ & Cement & 400 & 618.0 & 247.2 & 15 & 4 & 100 & 290 \\
\hline $\begin{array}{c}\text { C300FA200- } \\
\text { 40PCM-F }\end{array}$ & Cement & 300 & 602.2 & 240.9 & 15 & 3 & 200 & 295 \\
\hline $\begin{array}{c}\text { C200FA300- } \\
\text { 40PCM-F }\end{array}$ & Cement & 200 & 586.3 & 234.5 & 15 & 2 & 300 & 300 \\
\hline
\end{tabular}

Test procedures. The characterization of developed mortars was based on the workability, water absorption, microstructure, flexural behavior, compressive behavior and adhesion.

The workability tests were performed based on the flow table method stated by the European standard EN 1015-3, with the main goal of verifying the adequacy of application of the developed mortars [11]. The resulting value within the test was only considered when equal to $200 \pm 5 \mathrm{~mm}$.

The water absorption by immersion tests were based in the specification LNEC E 394 [12]. The samples were obtained by cutting the prismatic specimens with dimensions of $40 \times 40 \times 160 \mathrm{~mm}^{3}$, previously subjected to flexural tests. For each composition, 3 specimens were prepared, resulting in 6 samples after flexural tests. Initially the specimens were dried in an oven until the constant mass. Subsequently, they were saturated in water at a temperature of $20 \pm 3^{\circ} \mathrm{C}$. Finally, after saturation it was determined the hydrostatic mass.

The observation of the microstructure of developed mortars was performed using a scanning electron microscope. For each composition, two cylindrical specimens with diameter and height of approximately $1 \mathrm{~cm}$ were prepared. After their preparation all the specimens were stored during 7 days in polyethylene bags and subsequently placed in the laboratory at a constant room temperature (about $22^{\circ} \mathrm{C}$ ) during 21 days.

The mixture procedure and specimens preparation for the compression and flexural tests followed the standard EN 1015-11 [13]. For each composition three prismatic specimens with $40 \times 40 \times 160 \mathrm{~mm}^{3}$ were prepared. After their preparation all the specimens were stored during 7 days in polyethylene bags and subsequently placed in the laboratory at regular room temperature (about $22^{\circ} \mathrm{C}$ ) during 21 days. The flexural and compression behavior was determined based in the standard EN 1015-11 [13]. The flexural tests were performed with a machine speed of 50N/s. Compressive strength tests were done through the application of a load on the specimen held between metallic plates, rigid enough to make the vertical load uniform. The specimens used for the test were the half parts resulting from the flexural test. The compressive tests were performed with a load control at a speed of $150 \mathrm{~N} / \mathrm{s}$.

Regarding the adhesion tests, the mix procedure and specimens preparation was performed in accordance to the standard EN 1015-12 [14]. For each studied compositions 5 circular test areas with a diameter of $50 \mathrm{~mm}$ were prepared. After, all the specimens were stored during 7 days in polyethylene bags and subsequently placed in the laboratory at a constant room temperature (about $22^{\circ} \mathrm{C}$ ) during 21 days. 


\section{Test results and discussion}

Workability. According to Fig. 1 it was possible to identify changes in the amount of water added to the mortars with the incorporation of PCM microcapsules and fly ash.

It was possible to verify an increase in water content with the incorporation of PCM microcapsules. The incorporation of $40 \%$ of PCM leads to an increase in water content higher than $8 \%$ for all tested binders with exception of aerial lime based mortars. This can be explained by the reduced particle dimension of the used PCM and by the water absorption of the polymeric wall of the microcapsule.

The incorporation of fly ash in cement based mortars did not caused significant changes in the amount of water added to the mortars. However, it was possible to identify a slight reduction of water content for $20 \%$ of fly ash and a slight increase in the water content for the incorporation of $40 \%$ and $60 \%$ of fly ash, due to the presence of higher quantity of small size particles in the mortars. The decrease can be justified by the more spherical shape of the fly ash particles [15].

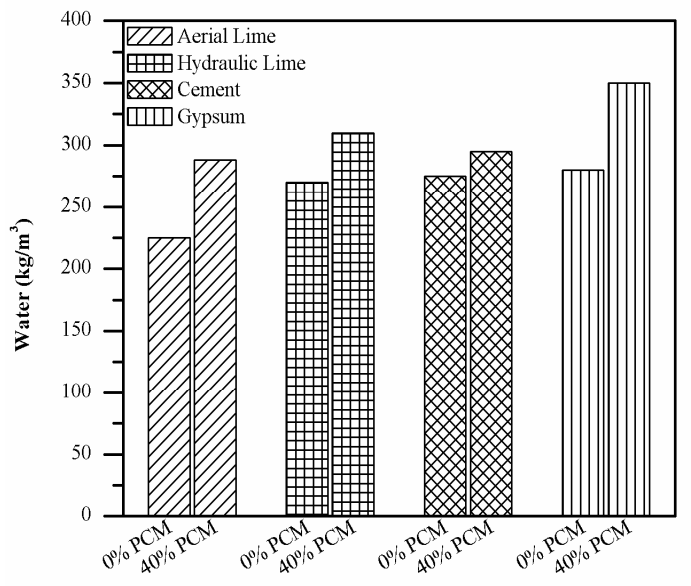

a)

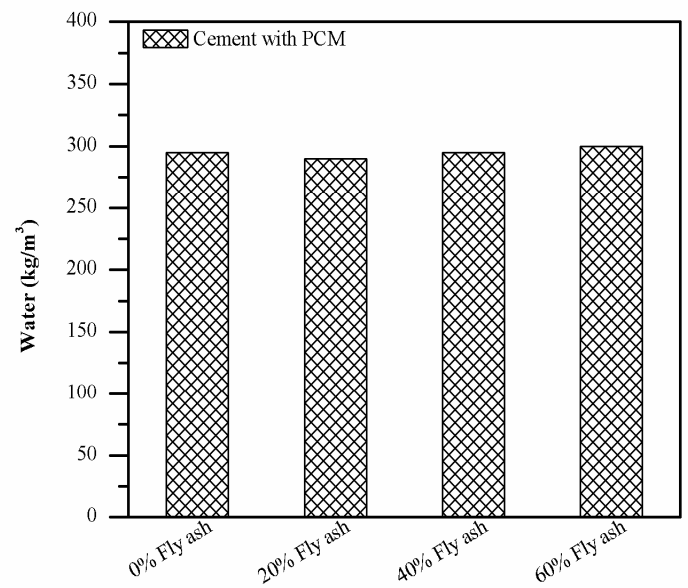

b)

Fig. 1. Water content of mortars: a) Mortars based in different binders with variation of PCM content, b) Cement based mortars with incorporation of PCM and variation of fly ash content.

Water absorption by immersion. According to Fig. 2 it was observed that the incorporation of $40 \%$ of PCM microcapsules in mortars caused an increase in water absorption by immersion higher than $8 \%$. This behavior can be justified by the presence of higher content of water in mortars with incorporation of PCM, which increase the microporosity.

Regarding the cement mortars with incorporation of fly ash, it is possible to observe that the incorporation of $20 \%$ of fly ash did not cause significant changes in the water absorption by immersion. However, it was possible to identify that the incorporation of $40 \%$ and $60 \%$ of fly ash caused a slight increase in the water absorption, due to the presence of higher ratio water/binder in these compositions.

Microstructure. Tests using the scanning electron microscope were performed in order to evaluate the existence of possible incompatibilities between the different materials present in the mortars. Fig. 3 shows the microstructure of different mortars with incorporation of $40 \%$ of PCM. For these observations it was possible to observe a good bonding between the different materials evidenced by the absence of cracks in the microstructure of the hydrated cement composite materials. It can be seen that the PCM microcapsules present a good and homogeneous distribution in the matrix. The PCM showed a good integrity, without signs of rupture or damages, which demonstrates that the microcapsules can resist adequately to the process of the mortar mixing, application and curing.

Fig. 4 shows the microstructure of cement mortars with incorporation of PCM and fly ash. It was observed a perfect connection between the hydrated binders (cement and fly ash) compounds.

Flexural and compressive behavior. According to the results, it was possible to observe a decrease in the flexural and compressive strengths caused by the introduction of PCM microcapsules and fly ash in mortars. 


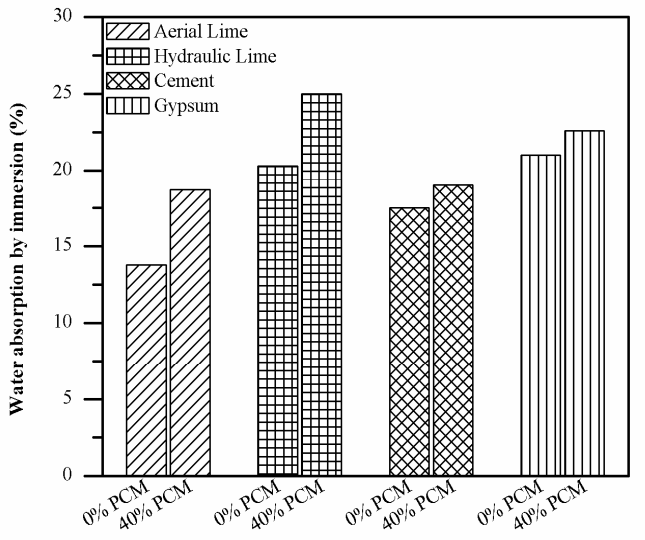

a)

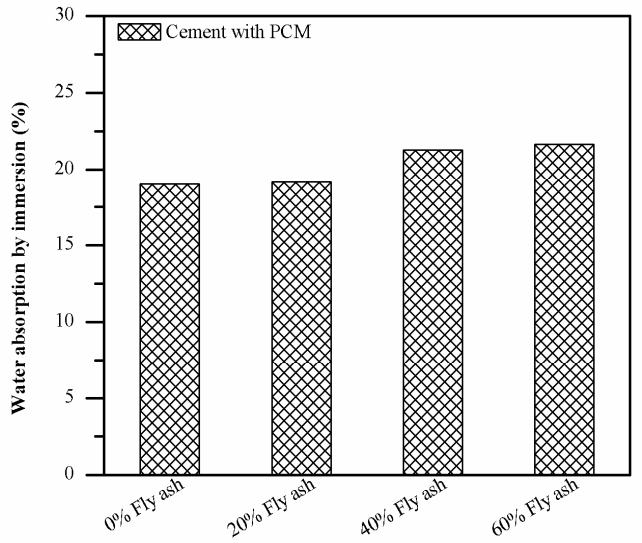

b)

Fig. 2. Water absorption by immersion of mortars: a) Mortars based in different binders with variation of PCM content, b) Cement based mortars with incorporation of PCM and variation of fly ash content.
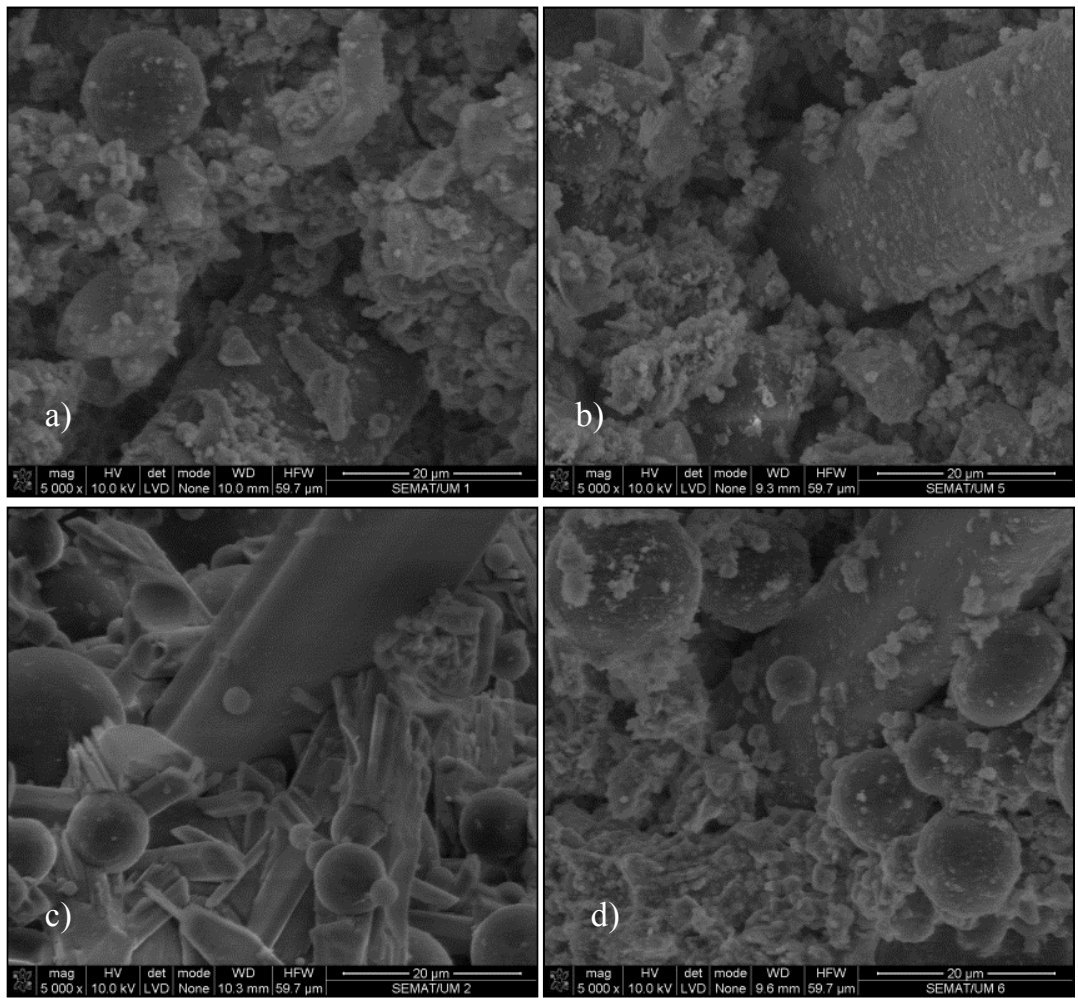

Fig. 3: Microstructure of mortars with incorporation of PCM: a) Aerial lime based mortar (AL80040PCM-F), b) Hydraulic lime based mortar (HL500-40PCM-F), c) Gypsum based mortar (G50040PCM-F), d) Cement based mortar (C500-40PCM-F).

Concerning the flexural strength (Fig. 5), the incorporation of 40\% PCM microcapsules resulted in a reduction compared to $28 \%$ PCM microcapsules, with exception of aerial lime based mortars which increase $150 \%$. This behavior can be justified by the increase of the water/binder ratio due to the introduction of a higher content of PCM which caused higher porosity in mortars. The incorporation of $20 \%$ fly ash in cement based mortars resulted in a decrease compared to $8 \%$ fly ash. This situation can be explained by the lower reactivity of fly ash when compared to the reactivity of the cement.

Regarding the compressive strength (Fig. 6), all tested mortars showed also a significant decrease with the incorporation of PCM. The incorporation of $40 \%$ of PCM microcapsules revealed a decrease in the compressive strength at least $60 \%$ when compared to the reference mortar, justified by the presence of higher content of water. It is also important to note that the adhesion 
between the PCM microcapsules and the matrix is lower than the bond strength between the sand particles and the matrix of the mortar.
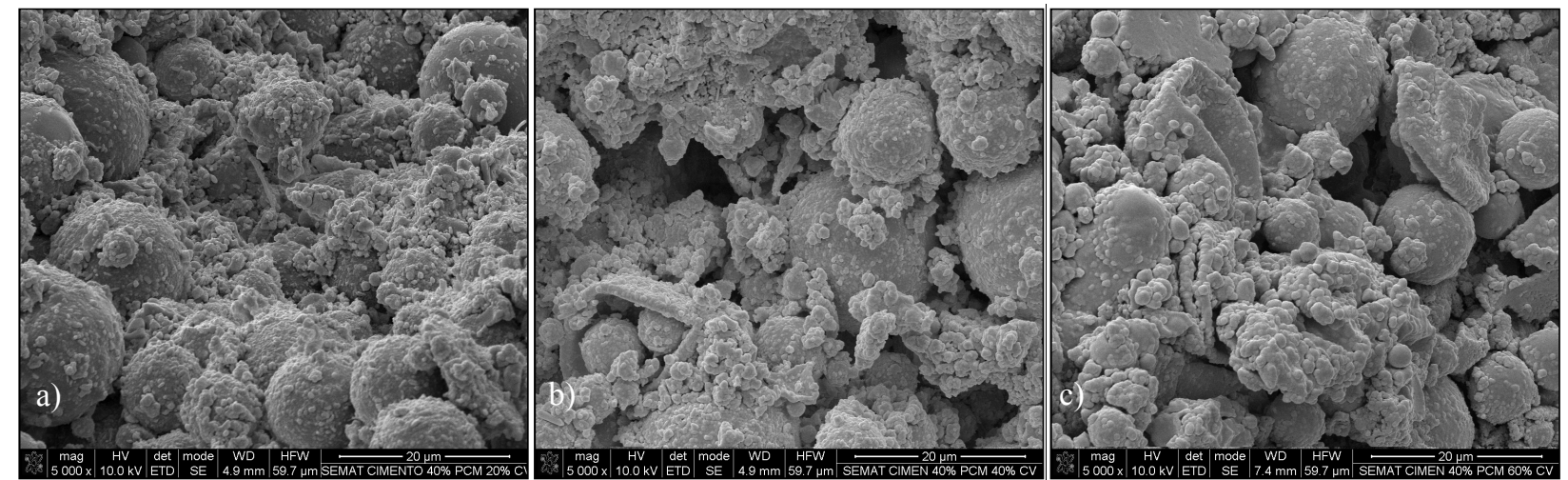

Fig. 4: Microstructure of cement mortars with incorporation of PCM and fly ash: a) 20\% of fly ash (C400FA100-40PCM-F), b) 40\% of fly ash (C300FA200-40PCM-F), c) 60\% of fly ash (C200FA30040PCM-F).

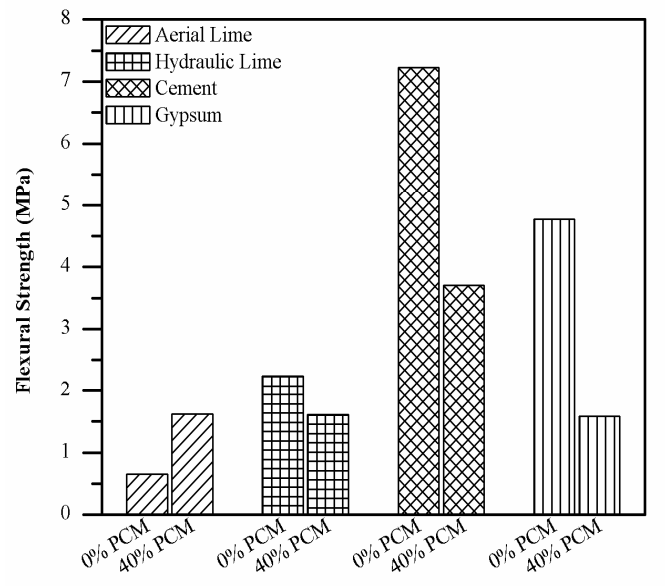

a)

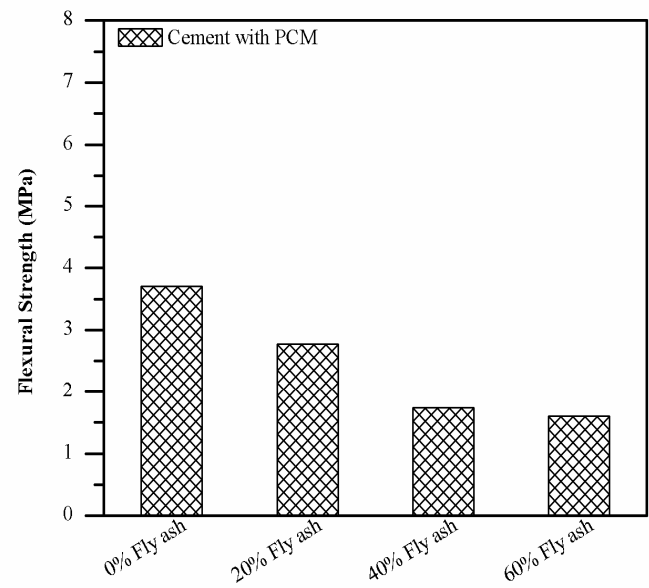

b)

Fig. 5. Flexural strength of mortars: a) Mortars based in different binders with variation of PCM content, b) Cement based mortars with incorporation of PCM and variation of fly ash content.

On the other hand, the PCM microcapsules possess a lower resistance compared with the sand particles. Thus, the replacement of the sand particles by a material with lower resistance (PCM) affects negatively the compressive strength. The incorporation of $20 \%$ fly ash revealed a decrease in compressive strength when compared to the reference mortar, due to lower reactivity of fly ash.

Adhesion. The adhesion tests allowed the estimation of the mortar adhesion when applied to a ceramic substrate frequently used in the construction industry for masonry. According Fig. 7 it was possible to observe a decrease in adhesion with the incorporation of PCM microcapsules and fly ash.

The incorporation of $40 \%$ PCM leads to a decrease in the value of adhesion higher than $33 \%$. This behavior can be explained by the lower adhesion between the PCM microcapsules and the matrix compared with the bond strength of the sand and the matrix of the mortar.

The incorporation of $20 \%$ of fly ash in cement based mortars leads to a decrease in the adhesion of $27 \%$, due to the lower reactivity of fly ash, when compared to the cement.

\section{Conclusion}

Based on the obtained results, it can be concluded that the incorporation of phase change material and fly ash in mortars for coating building interior walls causes significant changes in their properties in fresh and hardened state. 


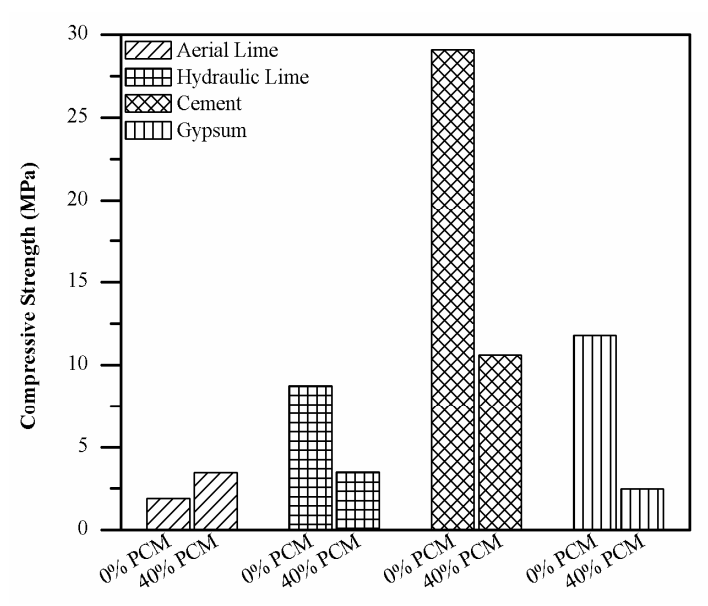

a)

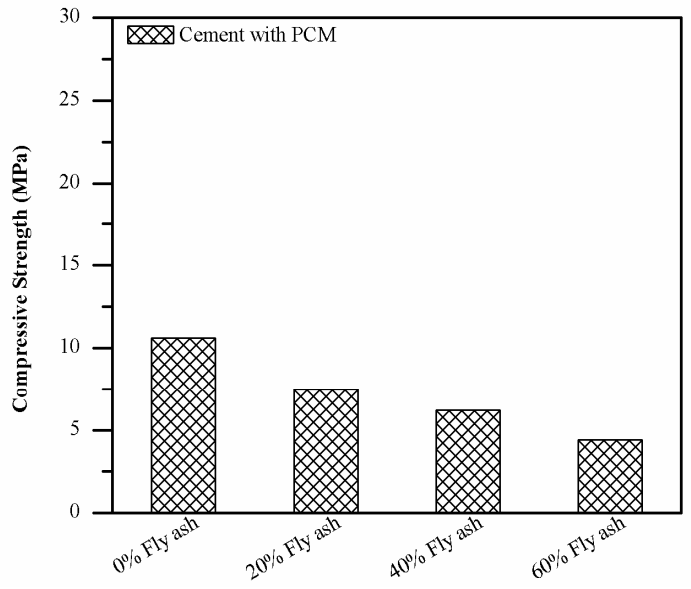

b)

Fig. 6. Compressive strength of mortars: a) Mortars based in different binders with variation of PCM content, b) Cement based mortars with incorporation of PCM and variation of fly ash content.

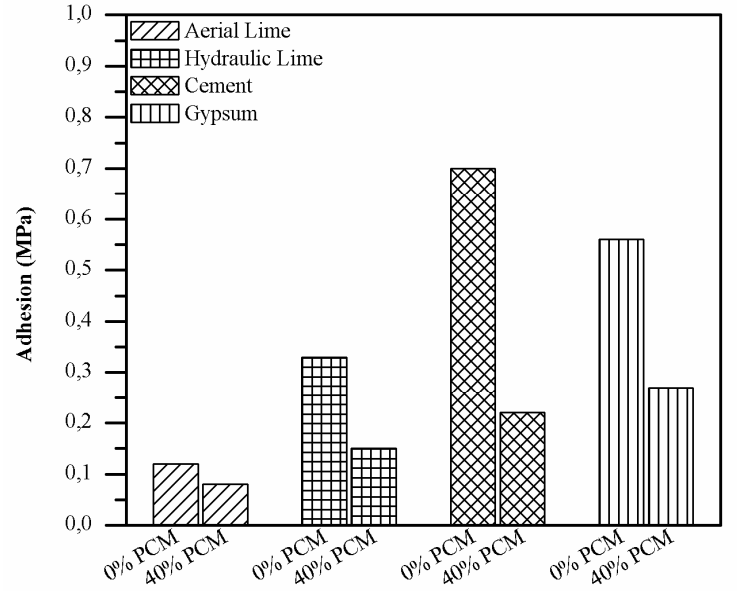

a)

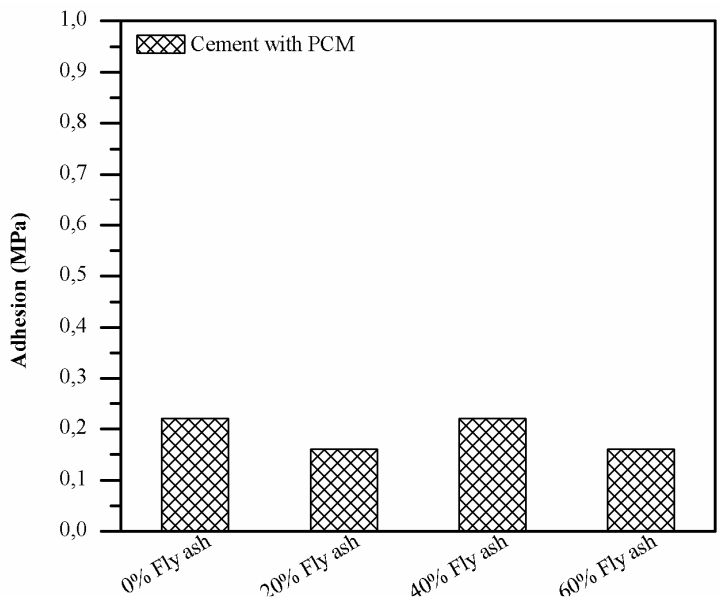

b)

Fig. 7. Adhesion of mortars: a) Mortars based in different binders with variation of PCM content, b) Cement based mortars with incorporation of PCM and variation of fly ash content.

Regarding workability, it was verified that the incorporation of PCM caused an increase in the amount of water added to the mortar in order to give a suitable workability. This increase in the water binder ratio is related to the fineness characteristics of PCM, requiring more water to obtain a homogeneous mortar. On the other hand, the incorporation of fly ash did not cause significant changes in the content of water added to the mixture.

The incorporation of PCM microcapsules in mortars caused an increase in water absorption, due to the presence of higher content of water in mortars with incorporation of PCM, which increase the microporosity. However the incorporation of fly ash did not lead to significant changes.

The study of mechanical strengths (flexural strength, compressive strength and adhesion) showed a decrease with the incorporation of PCM and fly ash. This phenomenon is a consequence of the presence of a larger amount of water, which leads to a higher porosity in mortars leading to decrease in the mechanical strengths and the lower reactivity of fly ash.

\section{Acknowledgement}

The authors acknowledge the Foundation for Science and Technology (FCT) for the financial support of the scientific cooperation programs between the Governments of Poland and Portugal and the PhD scholarship SFRH/BD/95611/2013. 


\section{References}

[1] M. Diamanti, M. Ormellese, M. Pedeferri, Characterization of photocatalytic and superhydrophilic properties of mortars containing titanium dioxide, Cement and Concrete Research 38 (2008) 1349-1353.

[2] A. Athienitis, C. Liu, D. Hawes, D. Banu, D. Feldman, Investigation of the Thermal Performance of a Passive Solar Test-Room with Wall Latent Heat Storage, Build Environ. 32 (1997) 405-410.

[3] L. Shilei, Z. Neng, F. Guohui, Impact of Phase Change Wall Room on Indoor Thermal Environment in winter, Energy Build. 38 (2006) 18-24.

[4] K. Darkwa, P. O'Callaghan, D. Tetlow, Phase-change drywalls in a passive-solar building, Appl Energy. 83 (2006) 425-435.

[5] P. Schossig, H. Henning, S. Gschwander, T. Haussmann, Micro-encapsulated Phase Change Materials Integrated Into Construction Materials, Sol Energy Mater Sol Cells. 89 (2005) 297-306.

[6] L. Cabeza, A. Castell, C. Barreneche, A. Gracia, A. Fernández, Materials used as PCM in thermal energy storage in buildings: A review, Renew Sustainable Energy Reviews. 15 (2011) $1675-1695$.

[7] M. Ahmad, A. Bontemps, H. Sallée, D. Quenard, Thermal Testing and Numerical Simulation of a Prototype Cell Using Light Wallboards Coupling Vacuum Isolation Panels and Phase Change Material, Energy Build. 38 (2006) 673-681.

[8] S. Cunha, J. Aguiar, V. Ferreira, A. Tadeu, Influence of the Type of Phase Change Materials Microcapsules on the Properties of Lime-Gypsum Thermal Mortars, Advanced Engineering Materials 16 (2014) 433-441.

[9] S. Cunha, J. Aguiar, V. Ferreira, A. Tadeu, Mortars based in different binders with incorporation of phase-change materials: Physical and mechanical properties, European Journal of Environmental and Civil Engineering (2015) (in press version).

[10] S. Cunha, V. Alves, J. B. Aguiar, V. M. Ferreira, Use of Phase Change Materials Microcapsules in Aerial Lime and Gypsum Mortars, Cement Wapno Beton, Special Issue (2012) 17-21.

[11] European Committee for Standardization (CEN). EN 1015-3:2004. Methods of test for mortar for masonry - Part 3: Determination of consistence of fresh mortar (by flow table) (2004).

[12] National Laboratory of Civil Engineering (LNEC). Specification E 394, ConcreteDetermination of water absorption by immersion (1993) (in Portuguese).

[13] European Committee for Standardization (CEN). EN 1015-11:1999. Methods of test for mortar for masonry - Part 11: Determination of flexural and compressive strength of hardened mortar (1999).

[14] European Committee for Standardization (CEN). EN 1015-12:2000. Methods of test for mortar for masonry - Part 12: Determination of adhesive strength of hardened rendering and plastering mortars on substrates (2000).

[15] A. Camões, P. Rocha, S. Jalali, J. B. Aguiar, R. Delgado, High-Performance Concrete Using Fly Ash, In Third Internacional Conference of High-Performance Concrete (2002) 15-32. 